\title{
ACADEMIC AND SPECIFIC, AIMED TRAINING TYPE EDUCATION POSSIBILITIES IN SCOPE OF CISCO NETWORKING ACADEMY TRAINING - NETACAD PROGRAM
}

\section{AKADÉMIAI RENDSZERŰ, ILLETVE SPECIFIKUS, CÉLTANFOLYAMI JELLEGÜ KÉPZÉSI LEHETŐSÉGEK A CISCO HÁLÓZATI AKADÉMIAI KÉPZÉS - NETACAD PROGRAM TÜKRÉBEN}

\author{
JOBBÁGY, Szabolcs \\ (ORCID: 0000-0002-2104-4665) \\ jobbagy.szabolcs@uni-nke.hu
}

\begin{abstract}
In my recent publication I analyse what other academic or specific, aimed training possibilities are at hand in each segment of either the defence or the civilian IT sphere, which can be integrated into the signals and information NCO professional training system at HDF NCO Academy in order to rethink and reshape it. All my research is based on a system of aspects, and on listing opinions pro and against, according to a level of matching, which can result in the most efficient and effective renewal of the professional training system being.
\end{abstract}

Keywords: NetAcad Program, Juniper Networks Academic Alliance (JNAA), Insular Telecommunication Network for Purpose of Government of Hungarian Defence Forces (ITNPG of HDF), Microsoft Virtual Academy, Hicom-Hipath training, NATO Communication and Information Systems School.

\begin{abstract}
Absztrakt
Jelen közleményemben azt vizsgálom, hogy milyen egyéb más akadémiai rendszerü vagy specifikus, céltanfolyami jellegü képzési lehetöségek állnak rendelkezésre akár a védelmi, akár a polgári szféra IT szegmensében, amelyek alkalmasak lehetnek a Magyar Honvédség Altiszti Akadémia híradó és informatikai honvéd altiszt és zászlósjelöltjeinek szakképzési rendszerébe történő beintegrálására, annak újragondolása, átalakitása érdekében. Mindezen vizsgálataim alapja egy szempontrendszer felállitása, és annak való megfeleltethetőség alapján érvek és ellenérvek felsorakoztatása, melyek a jelenlegi szakmai képzési rendszer lehetö leghatékonyabb és legcélravezetőbb megújitását eredményezhetik.
\end{abstract}

Kulcsszavak: NetAcad Program, Juniper Networks Academic Alliance (JNAA), $M H$ KCEHH, Microsoft Virtual Academy, HicomHipath tanfolyamok, NATO Communication and Information Systems School. 


\section{INTRODUCTION}

In my $\mathrm{PhD}$ thesis bearing the title „On developing the digital professional knowledge of the signals and information NCO and warrant officer operating personnel" I surveyed among other things, also the possibility of fitting the knowledge material of different courses and their modules reacheable on each level of CISCO Networking Academy Training - Netacad Program into the signals and information education portfolio of HDF NCO Academy, and also through which means that would be possible. My motivation to this was that in my hipothesis I assumed, that ,, the Hungarian Defence Forces (HDF) hasn't become fully able to adopt and convert the knowledge apropriate to the task and function system utilised in the leading NATO and European militaries into the professional NCO and warrant officer training. As a result, the signals and information education system at HDF NCO Academy doesn't meet the requirements of the age of digitalisation properly either. The professional digital knowledge reacheable within the training isn't meeting the technology and services utilised in the infocommunication network and digital systems of HDF fully. Thus the revising and reshaping of it is necessary. In zzthe frames of development of the human resource's digital knowledge the operating personnel can be outfitted with up-to-date professional knowledge and features, through which we can educate an expert for the organisation, at the same time posessing a knowledge valuable in the IT segment of the civilian sphere, being adversible and convertible. As a result we can also support their employment in the connecting fields of public service in case of leaving the organisation because of a changed career model, and their success in the market of civilian IT sphere as well." [1; pp. 9-10.]

During my research I highlighted the necessity and possibilities of rethinking and reshaping NQR54 NCO basic signals and military information system operator branch two years, full time, scholar education, and the complementary NQR55 warrant officer signals and information branch training type, state certified competency based modular education, thus verifying the scientific problem and the hypotheses set. I defined my scientific outcome based on these, according to which ,,by analysing the NetAcad Program and the professional training system of HDF NCO Academy, I verified that the revising of the training is necessary. On the other hand I also verified, that the network based academic education is suitable for this, its courses can be fitted into the NCO basic professional trainning, signals branch and sub-branches, also into the complementary warrant officer professional training, signals and information branch training system. Further I verified, that in the case of military information-system operator branch this is not necessary, buti t isn't possible either." [1; p. 200.]

One could rightly ask why I focused exactly on the possible integration of NetAcad Program, and what other similar academic type possibilities are accessable from the civilian IT sphere, which can be suitable to revise and reshape the relevant professional portfolio at HDF NCO Academy, and to outfit the future NCO-s and warrant officers with up-to-date theoretic and practical knowledge and shape their digital literacy.

\section{JUNIPER NETWORKS ACADEMIC ALLIANCE (JNAA)}

Of course, in the age of 21st century digital society we can find other means beyond the possibilities provided by NetAcad Program, to access up-to-date IT professional knowledge, digital competency and literacy, and internationally accepted certifications, either in form of academic education, or different specific, aimed trainings. This is no surprise, as according to the universal opinion of the experts, just as also Krisztina Horváth, managing director of CISCO Systems Hungary Ltd. declared in an interview: „, ... the three pillars of digitalisation can be defied in education, digital infrastructure and innovative surrounding and mentality...".[2] Thus, one of the most important pillars is education, which has endless possibilities among the circumstances of our age. Educating and training of professional experts has never been so easy 
to achieve like nowadays, as a result of access opportunity to different knowledge warhouses, databases ensuring gaining of information, online, e-learning education surfaces and global virtual communities.

During my research for the $\mathrm{PhD}$ thesis, when I decided to analyse the possibility and necessity of adapting this very form of education, I tried to view as many aspects as possible without being exhaustive, which stand for it compared to others. It is no secret that one of these was myself succeeding courses and modules in this system earlier, and taking part actively since almost seven years in its teaching via maintaining a CISCO Academy (CA) either on BA level or in form of training type education. As a result of these experiences, and also the outcome of my own survey (althought not being representative because of the low number of those answering), which I analysed and also involved in my thesis in form of graphs and diagrams [1; p. 242.], I got to the following assumption. The integration of the named training can be a useful segment of the professional NCO training, as it has been already integrated into the BA level education, or into the training type complementary training of already certified professionals in form of relevant courses and training frames. [1; pp. 73-76.] In accordance to the representativity of the survey above, all academic students are asked during the online tests closing each chapter and also before the final exams in form of ,course feedbacks" within the NetAcad Program in order to assure quality. I could base on the results of past years, and draw some conclusions on the success and usefulness in general to the justification of the network academy education. In this case, counting the past nine years of the Signals Department's CA, the number of those answering can be set between one and two hundred.

Even more important and uniform point of view was the answer to the following questions:

- the possibility and assumption of adoptibility from the side of the training program and its peculiarities

- the expectations of the military leadership, the professional superior

- the matching possibility to the criteria defined in the legislative background, and the requirements of the competency based modular professional training

- the recent hardvare platform giving technical fundament of HDF infocommunication network, and the digital systems of Insular Telecommunication Network for Purpose of Government of Hungarian Defence Forces (ITNPG of HDF), and the expected directions of future development

- international examples

- the evolving changes, expected trends and forecasts regarding the civilian IT sphere (standing future)

- the IT education maintained in the different training systems and educational institutes of the civilian sphere

I also strived to give a reason to all these aspects of research in my work.

Based on these and through further research the following answer can be given. Beyond NetAcad Program, for example also Juniper Networks is providing similar type of education. Because of volume reasons I will not introduce every aspect of this, I will try only to draw its peculiarities, main characteristics grasping the elemental parts of it, parallel with the network academy education.

The company is a leading actor in the IT segment, also playing a key role in the network innovation field. Foremostly they aimed to invent such technology that helps their customers to merge their ideas with the world of networks, enabling their adversibility and possibility to develop in this constantly changing world. To meet this, beyond striving to create state of the art technology and tools, and deliver converged services, they also set the goal of spreading knowledge, cooperation and human development in each branch of industry, like energy, healthcare or education. Although $80-90 \%$ of the routers, switches and other passive and active 
network devices in the network infrastructure of the internet are provided by CISCO, the biggest cable and wireless, satellite, internet, cloud and datacenter providers of the world are cooperating with Juniper Networks as well. [3]

The company strives within the frames of Juniper Networks Academic Alliance (JNAA) program to deliver and bring closer the solutions developed by them in a resilient and innovative way to either their clients or the scientific community, developing a strong relation with them. Two vitally important pillars of that are education and research. Within the first they provide such training opportunities, which like the NetAcad Program, provide certification in engineering and fields of industry. On the other hand, in order to realize this, they provide the necessary theoretical material for the teachers either in electronic or printed form, which can be fitted within the education program of the given institute, meeting their peculiarities. Beyond all these they provide laboratory hardware as well, to which the partaker can have preferential access. As a result, they deliver in summary approach to the leading technology and resources of the industry in the fields of engineer education, evaluation, research and decelopment. The most important fields within this are for example the state-of-the-art network protocols, security and threat management, green networks, network automatisation, virtual networks etc. Under the research pillar, they lead high level academic projects and researches. [4]

According to these, the benefits of this program can be summarised as follows:

- access is granted to the education material and other resources of Juniper Networks for the teachers and the students as well

- the further training of the teachers is provided

- teacher and student evaluation can be reached in a preferential way

- the opportunity to aquire the necessary laboratory hardware and developing of virtual laboratory environment is secured preferentially

- job opportunities to the evaluated students of the industry

- the possibility to attend international competitions for the students

The program is open and accessible to all credited intitutions, also especially for the armed forces. Similary to NetAcad, also here a hierarchic evaluation program has been developed, named Juniper Networks Certification Program (JNCP), which enables the students to get certifications verifying each competency according to the given education field and level. This is pictured in the diagram below. I won't detail each education and evaluation level further because of volume reasons.[4] 


\section{Juniper Networks Certification Program Framework}
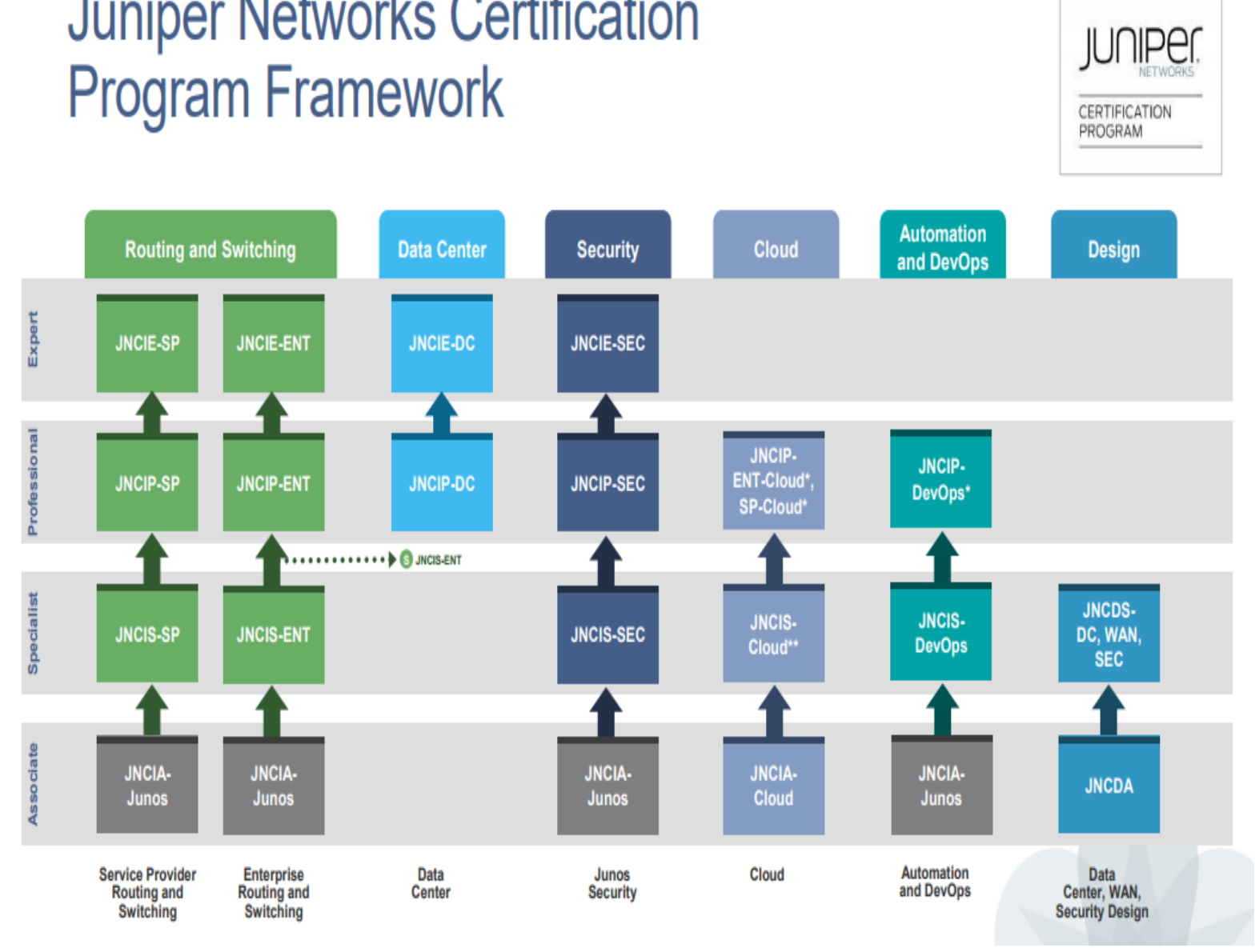

1. Figure Juniper Networks Certification Program (JNCP)[5]

As it can be seen above, in this system similar education and evaluation levels can be found as in NetAcad Program, for professionals to be trained on initial, comprehensive, professional and expert level in fields like routing and switching, data centers, security, cloud computing, automatisation, and network planning. Analyzing these I have found, that all the general and basic technology, protocol, standard, policy and terminology regarding networks, so the basic knowledge in general can be found here as well, just like in the courses and modules of the network academy education.[1; pp. 73-128.] The biggest difference lays in the hardware platform, which defines the operation of each network device and the peculiarities of the necessary network operation system for this. This latter aspect is the strongest opnion in my view to decide for the integration of NetAcad Program into the education of NCO-s and warrant officers. The table below holds the peculiarities and attributes of each program, and their fitting to the point analised earlier in this article. 


\begin{tabular}{|c|c|c|}
\hline & $\begin{array}{l}\text { CISCO NetAcad } \\
\text { Program }\end{array}$ & $\begin{array}{c}\text { Juniper Networks } \\
\text { Academic Alliance } \\
\text { (JNAA) }\end{array}$ \\
\hline \multicolumn{3}{|c|}{ Peculiarities and attributes of the education programs in comparison } \\
\hline $\begin{array}{l}\text { Access to online education surface and material granted (e- } \\
\text { learning)? }\end{array}$ & Yes & Yes \\
\hline $\begin{array}{l}\text { Connection to a virtual global education and work market } \\
\text { community granted? }\end{array}$ & Yes & Yes \\
\hline Further training of the teachers granted? & Yes & Yes \\
\hline Laboratory environment for education granted? & Yes & Yes \\
\hline $\begin{array}{l}\text { Maintaining internationally credited evaluation system in the } \\
\text { industry? }\end{array}$ & Yes & Yes \\
\hline $\begin{array}{l}\text { Possibility to the students to measure their knowledge at } \\
\text { domestic or international competitions granted? }\end{array}$ & Yes & Yes \\
\hline \multicolumn{3}{|c|}{$\begin{array}{l}\text { Comparing the possibility and necessity to integrate into the professional education } \\
\text { system according to given aspects }\end{array}$} \\
\hline $\begin{array}{l}\text { Possibility and circumstances to adopt given by the peculiarities } \\
\text { of the education system? }\end{array}$ & Yes & Yes \\
\hline $\begin{array}{l}\text { Meeting the requirements of the military higher command and } \\
\text { the professional superior? * }\end{array}$ & Yes* & Yes (partly)* \\
\hline $\begin{array}{l}\text { Meeting the criteria defined by the regulatory background, and } \\
\text { the requirements of the competency-based modular training } \\
\text { system?* }\end{array}$ & Yes* & Yes (partly) * \\
\hline $\begin{array}{l}\text { Matching the hardware platform providing the technological } \\
\text { foundation of the infocommunication network and digital } \\
\text { systems of HDF, and the expected future development } \\
\text { directions?* }\end{array}$ & Yes* & No * \\
\hline International examples $*$ & Yes* & Yes (partly)* \\
\hline $\begin{array}{l}\text { Meeting the changes within the civilian IT sphere, and the } \\
\text { future trends and expectations? }\end{array}$ & Yes & Yes \\
\hline $\begin{array}{l}\text { Has been integrated into IT education within Hungarian } \\
\text { civilian education at any level and institution? * }\end{array}$ & Yes* & No* \\
\hline
\end{tabular}

1. table Fitting NetAcad Program, and JNAA program into the Hungarian NCO and warrant officer professional training, meeting the requirements of integration possibility and necessity (edited by the author)

Summarising the above, I would add to my previous answer the followings. Although, there is a similar education program already existing, showing a great similarity to NetAcad Program, taking the possibility and necessity to integrate into $\mathrm{NCO}$ and warrant officer training into account, and analising the aspects of that, based on the points given with italics in the table, I still propose clearly to adopt NetAcad Program. Possibilities provided by JNAA Program hardly or do not meet the requirements and expectations in some of the aspects. Some of these:

- althought it can provide almost all the basic professional knowledge, digital competency, digital literacy as NetAcad, thus meeting the expectations of the professional superior, and the legislative requirements [6; (Appendix 3.)], however given to the recent hardvare platform and digital systems of HDF, it cannot prepare the NCO and warrant officer applicants to operate these specific to the used devices 
- as already pictured in my thesis [1; pp. 68-71.], the planned directions of development support also that even greater asset orientation and implementation of recent CISCO hardvare platform will happen with the generation shift of network tools. This makes the revision of the professional education reasonable in an according way, and also the integration of necessary knowledge material within.

- it is also supported by international examples of assets used in other militaries, and also the international training possibilities as mentioned in my thesis, which provide the opportunity to develop CISCO specific knowledge next to up-to-date professional education, or already require these as obligatory term of application (e.g. NATO Communications and Information Systems School, Latina: „Deployable Optical Fibre Cable”, „MiniPoP Operator”, „MiniPoP Familiarisation”, „DCIS Transmission/Network Integration Foundation (Online)”, „Cisco On-Line CCENT (ICND1)”, „NATO Networking Infrastructure (Cisco CCNA Routing \& Switching)”, „NATO Voice over IP Foundation Course Version 2.1”).[1; 79-80. o.]

- and, as also highlighted in my thesis, in case of the trainings within the national education system of civilian IT sphere, according to the recent trends and the forecasts, NetAcad Program will provide the necessary educational background. The program can deliver a solution to decrease the so many times mentioned lack of IT experts. One proof of this - bejond that the knowledge material of each course already almost exactly meets the requirements of the education plan [1; pp. 98-108.] - is also that the institutes can utilise Packet Tracer network simulation program, developed by CISCO, reacheable since 2017 for free either for training purposes or at professional final exams.

\section{SPECIFIC, GOAL ORIENTED TRAINING POSSIBILITIES}

Some further thoughts can be added to the original question, which can provide some options on training the certified NCO-s and warrant officers and widen their professional knowledge beyond the possibilities of NetAcad Program, and based on the knowledge gained through it.

Given that the timeframe for the NCO certification is two years, and that of the warrant officers is three months, and having analysed the recent frame education plan for the first [7] and the relevant education program for the latter [8], it has to be seen, that because of the structure of those, there is no possibility to integrate other up-to-date professional training beyond NetAcad Program's knowledge material within them.

Nevertheless, later on, in order to outfit the NCO or warrant officer after the certification already fulfilling professional assignment, with the up-to-date professional knowledge possibly still lacking, either through further training or complementary education based on the already given knowledge of the network academy education, I see the following specific trainings to be adviseable in general as main directions. It can be achieved either through specific trainings in the civilian IT sphere, or at Signals Department of NUPS FMSOT [9; 10], or utilising the education portfolio of any other relevant department, within goal-oriented trainings after their necessity and reasonability has been proved by according surveys.

- trainings reacheable within the official Microsoft Virtual Academy (MS VA) set to existance in 2013 (e.g. operation system, security, firewall, virtualisation, remote management, cloud computing, etc.) [11]

- different cyber trainings

- trainings regarding information security (e.g. system administrator, cyphering, etc.) [12; pp. 68-69]

- Hicom - HiPath operator and programmer training 
- NATO Communications and Information Systems School, Latina-provided trainings [13]

The achieving of these education and training options in a complementary and comprehensive approach can be reasonable and necessary depending on the fulfilling of each professional assignment, and according to a survey on demand as mentioned earlier, since the knowledge material provided can widen the knowledge, thus making the expert able to fulfill for example device specific tasks at a higher level. This can be understood for example as like information and cyber security affects the work of every professional in a direct or indirect way, and will have an ever greater effect on the digital society, which also comprises among other of different law enforcement organisations, thus also HDF within. Knowledge on workstations and their operational system within network infrastructure from network configuration perspective can be necessary in order to implement, tune, and manage the network also to maintain security settings [14] and troubleshooting. As a result of already mentioned future changes in the digital systems of HDF infocommunication network, it can be reasonable to gain knowledge on the operation of Hicom and HiPath switch centres, and their settings in order to connect them for example with VoIP phone center in the period of change. The knowledge on emulation utilisation of a terminal, through which the configuration of network devices happens, can provide a fundament when we try to reach a Konsberg or Harris radio in order to transmit data.

We also have to mention - not necessary as a hindrance - that these trainings, given their goal oriented approach, mainly focus only on a narrow part of their field. In comparison, the education analysed in my research also bears knowledge material on device specific knowledge in it, at the same time it also provides a solid, basic and general knowledge, which can serve as a strong pillar for the future achieving of goal oriented training later on. Of course, it is not possible, nor necessary to provide every expert with all the knowledge, it is more reasonable to show them the approach and opportunities in accordance with the words of Albert SzentGyörgyi, as cited at the beginning of my thesis. [1; p. 5.]

\section{CONCLUSION}

Based on our answers to the question we can conclude as follows. Within the possibilities of the digital society in 21 st century, with a scope on the necessity of education, training and preparing we can state that yes, there are other programs beyond NetAcad, with a similar academic type training possibility, like JNAA Program by Juniper Networks. However, matching it with the aspect-system taken that as a fundament, and analysing the corresponse to it, the possibility and at all the necessity to integrate it, we can state that JNAA does not meet each expectation and requirement fully. Thuss I still regard the opportunity provided by NetAcad Program as most appropriate to rethink and revise the relevant education portfolio of HDF NCO Academy's professional education system. Furthers there is a possibility to gain upto-date professional knowledge, digital competency and digital literacy through several other forms of education; however these are mostly specific, goal-oriented types of providing knowledge. Thus, given that their knowledge base is not general, nor complex, but more particular, I regard them as being able to provide training for the operator personnel after the professional certification to broaden their knowledge in a reasonable case. 


\section{BIBLIOGRAPHY}

[1] JOBBÁGY Szabolcs: A honvéd altiszt és zászlós híradó és informatikai üzemeltető állomány digitális szakmai ismereteinek fejlesztése; doktori (PhD) értekezés; Budapest 2018.

[2] Szakképzés-fejlesztéssel az informatikushiány ellen; https://www.hwsw.hu/hirek/56267/cisco-halozati-akademia-iskola-oktatas-erettsegipacket-tracer.html (Downloaded: 26.06.2018.)

[3] Juniper Networks; https://www.juniper.net/us/en/company/profile/ (Downloaded: 27.06.2018.)

[4] Juniper Networks

Academic

Alliance (JNAA); https://www.juniper.net/uk/en/training/academicalliance/ 27.06.2018.)

[5] Juniper Networks Academic Alliance Certification Program Framework (JNAA),http://www.junipercertified.com/certifications/juniper-certification-framework/ (Downloaded: 27.06.2018.)

[6] A Kormány 217/2012. (VIII. 9.) kormányrendelete az állam által elismert szakképesítések szakmai követelménymoduljairól; http://www.budapestedu.hu/data/cms150131/Mk_106_217_2012.(VIII.99.)_Korm._re ndelete az allam altal elismert szakkepesitesek szakmai_kovetelmenymoduljairol.pdf (Downloaded: 02.07.2018.)

[7] 2.69 Szakképzési Kerettanterv az 5486302 Honvéd Altiszt Szakképesítéshez, valamennyi ágazatához/szakmairányához; https://www.nive.hu/index.php?option=com_content\&view=article\&id=731 (Downloaded: 05.07.2018.)

[8] Képzési Program, Honvéd zászlós tanfolyam, Híradó és informatikai szakirány.- HVK HIICSF.

[9] FARKAS T.: Signal Officer Training at the National University of Public Service (Budapest, Hungary) In: ŠOSTRONEK M., BEREŠIK R., BABJAK M., SPILÁ D. (szerk.) New Trends in Signal Processing 2014: Proceedings of the International Conference: 15-17 October 2014, Tatranské Zruby, Slovakia. Konferencia helye, ideje: Tatranské Zruby, Szlovákia, 2014.10.15-2014.10.17. Liptovski Mikulas: Armed Forces Academy of General Milan Rastislav Štefánik, 2014. pp. 37-43.

[10] FARKAS T.: CIS officer training at the National University of Public Service: capabilities and requirements In: Hruby M. (szerk.) Distance Learning, Simulation and Communication (DLSC) Conference. Konferencia helye, ideje: Brno, Csehország, 2015.05.19-2015.05.21. Brno: University of Defence Faculty of Military Technology, 2015. pp. 84-90.

[11] Microsoft Virtual Academy; https://mva.microsoft.com/ (Downloaded: 07.07.2018.)

[12] MÓGOR Tamásné: Az emberi tényező szerepe az információbiztonság megvalósítása és erősítése terén. Az információbiztonsági kultúra fejlesztésének lehetőségei a Magyar Honvédségben; Doktori (PhD) értekezés; Budapest 2017. 
JOBBÁGY: Academic and specific, aimed training type education possibilities in scope of cisco networking...

[13] NATO Communications and Information Systems School, Latina; https://www.nciss.nato.int/ (Downloaded: 07.08.2017.)

[14] MEGYERI Lajos: Elektronikus információs rendszerek biztonsági menedzsmentje; Müszaki Katonai Közlöny vol. XXVIII. No. 2. (2018) 